\title{
Chronic cancer pain management by the nursing team
}

\author{
Manuseio da dor crônica em pacientes oncológicos pela equipe de enfermagem
}

\author{
Anara da Luz Oliveira ${ }^{1}$, Natália da Palma Sobrinho², Beatriz Aparecida Silva Cunha²
}

DOI 10.5935/1806-0013.20160075

\section{ABSTRACT}

BACKGROUND AND OBJECTIVES: Cancer patients' pain is related to the tumor, to diagnostic and therapeutic procedures and to the terminality of the disease; however health professionals, especially nursing teams, still have difficulties in evaluating and managing pain. As from experience in hospitals, it was noticed that nursing teams face barriers, which is intensified in case of cancer patients, marked by the "incurable" cancer pain stigma. This study aimed at identifying in the literature, how nursing teams manage chronic cancer pain.

CONTENTS: We have found 710 articles being 194 in LILACS and 516 in Scielo, being included 14 articles by means of the descriptors "Nursing Care", "Nursing", Chronic pain", "Pain management", "Oncology". In the category "Cancer pain management by the nursing team", studies have reinforced the importance of pain evaluation by the nursing team and present resources and strategies to make it effective. In the category "Pharmacological methods for pain management", drugs appear as the first method of choice with the three steps stair of the World Health Organization and opiophobia is discussed. In the category "Non-pharmacological methods for pain management", there are interventions such as therapeutic massage, spiritual support and comfort measures, such as changing position.

CONCLUSION: Assisting painful cancer patients goes beyond performing procedures; it is necessary to think about scientific knowledge acquisition and professional-patient link for a safe assistance when managing cancer pain.

Keywords: Chronic pain, Nurse-patient relationships, Nursing, Nursing care, Oncology, Pain management.

1. Universidade Federal do Estado do Rio de Janeiro, Instituto Nacional do Câncer, Hospital Naval Marcílio Dias, Rio de Janeiro, RJ, Brasil.

2. Universidade Federal do Estado do Rio de Janeiro, Hospital Naval Marcílio Dias, Departamento de Enfermagem, Rio de Janeiro, RJ, Brasil.

Submitted in February 28, 2016.

Accepted for publication in June 20, 2016

Conflict of interests: none - Sponsoring sources: none.

Correspondence to:

Praça Cruz Vermelha, no 23, Centro

20230-130 Rio de Janeiro, RJ, Brasil.

E-mail: anaraluzoli@yahoo.com.br

(C) Sociedade Brasileira para o Estudo da Dor

\section{RESUMO}

JUSTIFICATIVA E OBJETIVOS: A dor no paciente oncológico se relaciona à presença do tumor, aos procedimentos diagnósticos e terapêuticos e à terminalidade da doença, porém os profissionais de saúde, particularmente a equipe de enfermagem, ainda apresentam dificuldades na avaliaçáo e manuseio da dor. A partir da vivência nos hospitais, percebeu-se que a equipe de enfermagem enfrenta barreiras, o que se intensifica ao se tratar de um paciente oncológico, marcado pelo estigma da dor "incurável" do câncer. O objetivo deste estudo foi identificar, na literatura, como a equipe de enfermagem manuseia a dor crônica nos pacientes oncológicos.

CONTEÚDO: Foram encontrados 710 artigos, sendo 194 no LILACS e 516 no Scielo; aproveitando-se 14 artigos, com uso dos descritores "Cuidados de Enfermagem", "Enfermagem", "Dor crônica", "Manejo da dor", "Oncologia". Na categoria "Manejo da dor oncológica pela equipe de enfermagem", os estudos reforçam a importância da avaliaçáo da dor pela equipe de enfermagem e apresentam recursos e estratégias utilizados para efetivá-la. Na categoria "Métodos farmacológicos para o manuseio da dor", o fármaco aparece como primeiro método de escolha com a escada de três degraus da Organizaçáo Mundial da Saúde e discute-se a opiofobia. Na categoria "Métodos não farmacológicos para o manuseio da dor", tem-se intervençóes como massagem terapêutica, apoio espiritual e medidas de conforto, como mudança de decúbito.

CONCLUSÁO: Cuidar do paciente oncológico com dor ultrapassa a execução de procedimentos; é preciso pensar na aquisição de conhecimento científico e vínculo profissional/paciente para uma assistência segura no manuseio da dor oncológica.

Descritores: Cuidados de enfermagem, Dor crônica, Enfermagem, Manuseio da dor, Oncologia, Relaçóes enfermeiro-paciente.

\section{INTRODUCTION}

Pain is a subjective and individual experience associated to physical, cognitive, cultural and psychological manifestations. In 1979, the International Association for the Study of Pain (IASP) has standardized and made international the concept of pain, and has defined pain as "unpleasant, emotional and sensory experience associated to real or potential tissue injury or described in such terms" ${ }^{1}$. In oncology, the concept of pain was introduced by Cicely Saunders as "Total Pain", where pain is made up of several components: physical, social, mental and spiritual ${ }^{2}$. Cancer pain is related to tumor and the presence of me- 
tastases; it may be induced by diagnostic and therapeutic procedures which may be uncomfortable; and also may be caused by disease terminality ${ }^{2-4}$.

The prevalence of cancer pain is estimated in 25 to $50 \%$ for recently diagnosed patients, in 33 to $80 \%$ for patients under treatment, and in approximately 75 to $100 \%$ for those in advanced and terminal states ${ }^{5}$.

Although statistics being alarming regarding cancer pain incidence, studies have shown that the adoption of therapeutic strategies may improve pain in 80 to $90 \%{ }^{2,6,7}$.

Pain is part of healthcare routine, be it during hospitalization or outpatient treatment, however health professionals still have difficulties in evaluating and managing pain $^{5,8,9}$.

Insecurity with regard to regular use of morphine and difficulties to administer drugs when requested versus regular analgesia have intensified concerns about the subject. So, based on the assumption that understanding pain events in cancer patients is extremely important, this study aimed at evaluating chronic pain management in cancer patients by the nursing team.

\section{CONTENTS}

This is a narrative literature review as from queries in Latin-American and Caribbean Literature in Health Sciences (LILACS) and Scientific Electronic Library (Scielo). Descriptors were Nursing Care, Nursing, Chronic pain, Pain management, Oncology, Cancer, Nurse-Patient relationships.

Inclusion criteria were articles in Portuguese language and published from 2010 to 2015. Exclusion criteria were articles not published by nurses. We have found 710 articles, being 194 in LILACS and 516 in Scielo. After initial analysis by reading abstracts and checking appropriateness to theme, 23 articles were selected, being 8 from LILACS and 13 from Scielo.

By means of subsequent analysis and application of exclusion criteria, 14 articles were selected and, as from thorough reading, results were organized in categories.

For the category "Cancer pain management by the nursing team", articles have described pain as the fifth vital sign, and so it is believed that the nursing team is linked to possible interventions to relieve it ${ }^{10}$; however, there are reports on difficulties to manage cancer patients' pain and to implement adequate therapies ${ }^{11}$.

There might be difficulties in listening to patients' pain complaints, although nurses understand the complexity of the experience and are sensitive to the theme ${ }^{12}$.

Two basic principles are critical to manage cancer pain: total pain involving physical, environmental, emotional, social and spiritual factors and identification of mechanisms inducing and worsening pain ${ }^{13}$.

Most studies mentioning cancer pain management by the nursing team have also presented resources and strategies to be used to minimize $\mathrm{it}^{13}$.
All nurses have to know the tools used to measure pain intensity, which requires specific qualifications and skills focused on improving pain ${ }^{14}$.

Lima et al. ${ }^{5}$ have emphasized the use of pain scales, because they may attribute objectivity to the subjective aspect of pain experience. Cunha and Rego ${ }^{11}$ presented visual analog scale (VAS) and numerical verbal scale (NVS) as the most widely used scales.

For the category "Pharmacological methods for the management of cancer pain by the nursing team", few studies were found addressing the subject.

Study of Chotolli and Luize ${ }^{10}$ has reported that the use of drugs seems to be the first method of choice for pain relief. Among these drugs, anti-inflammatory, opioids, antidepressants, and anticonvulsants, among others, were the most commonly mentioned ${ }^{15}$.

Pharmacological treatment, according to the three steps ladder proposed by the World Health Organization (WHO) is the basis to control cancer pain ${ }^{7,16}$.

WHO states that morphine and its derivatives are underutilized worldwide and in Brazil. This may be related to fear (opiophobia) and/or lack of knowledge of opioids' pharmacology and clinical use. This situation, although very common among nurses, has not yet been adequately studied ${ }^{7}$.

The only approach was mentioned by Simóes ${ }^{17}$, who cautions that non-treatment of pain due to "lack of knowledge", "fear of adverse reactions" or negligence is a serious violation of perfectly established bioethical principles.

Drugs may control pain, but not the whole context involving cancer patients. In this sense, there is the category "Non-pharmacological methods for cancer pain management by the nursing team", where studies bring interventions such as therapeutic massage, spiritual support and comfort measures, such as changing position in bed. There is also an article mentioning interventionist procedures ${ }^{16}$.

Massage seems to be useful to relieve pain and improve mental health, although there are still questions about the efficacy of this protocol. However, it may contribute to promote wellbeing and improved quality of life $\mathrm{e}^{18,19}$.

With regard to methods thought by nursing professionals to manage pain, the frequency with which they appeared was: $10(38.4 \%)$ for drugs, $9(34.2 \%)$ for distraction, 2 (7.6\%) for lap, 2 (7.6\%) for affection, 1 (3.8\%) for decreasing noise and 1 (3.8\%) for therapeutic touch ${ }^{10}$.

It is important to stress that even with drugs and complementary therapies, there is not always success in suppressing pain ${ }^{7,15}$.

Nurses, as part of a multidisciplinary team, actively intervene to totally control and relief pain by means of non-pharmacological interventions and should know pharmacological treatments, as well as indications, contraindications and adverse effects ${ }^{19,20}$.

Table 1 shows articles organized in this study by categories. 
Table 1. Articles included in the study, according to category

Category 1. Cancer pain management by the nursing team

\begin{tabular}{lcll}
\hline Article & Year & Type of study & Objective \\
Nurses and cancer pain & 2015 & $\begin{array}{l}\text { Integrative lite- } \\
\text { rature review }\end{array}$ & $\begin{array}{l}\text { Identify in Brazilian scientific production the } \\
\text { status of nursing team assistance and know- } \\
\text { ledge of cancer pain. }\end{array}$
\end{tabular}

Palliative care: pain evaluation according to nurses

Postoperative management of cancer pain patients by nurses

Spiritual dimension in pain and suffering control of advanced cancer patients

Dialogues with nurses about oncologic pain aspalliative care. sessment of patients under
2010 Convergent-astative research

2013 Descriptive qualitative study

2015 Case report

2010 Experience report sistential quali-
Reveal concepts and contributions of nurses acting in palliative care about cancer patients' pain evaluation

Describe the management of immediate postoperative pain of cancer patients by the nursing team

Show the integration of spiritual aspects in pain sensation manifestation and their influence on pain and suffering control of advanced cancer patient.

Report the experience of developing a labor education process focused on the awareness of nurses about pain evaluation of patients under palliative care

\section{Conclusion}

Results have contributed for the scientific armamentarium of the nursing team, giving it support for better pain management with regard to its adequate measurement, major intervention aspects and predominant stumbling blocks for fighting against pain.

Implementation of systematized pain management entailed in nursing assistance systematization enables redirecting actions and this way a more complete and effective pain management.

Nursing team should be prepared to manage postoperative pain of cancer patients, with the use of available tools and identification of pharmacological and complementary interventions needed for each patient.

Importance of recognizing the spiritual dimension in adequate total pain evaluation

Nurses stress the need to build pain evaluation systematization so that nurses may reinforce the importance of its control, and justify practice and ongoing education.

Category 2. Pharmacological methods for the management of cancer pain by the nursing team

Irruptive pain in advanced 2011 Literature re- Systematize pain concepts and definitions ascancer view sociated to cancer, understand onset mechanisms of irruptive pain and know the best ways to relieve it.

Severe non-relieved pain brings adverse physical, psychological and social consequences. Patients have the right to adequate treatment.

Non-treatment of pain by "fear of adverse reactions" or by negligence leads to serious violation of bioethical principles.
Avaliação da dor em pacientes oncológicos internados em um hospital escola do Nordeste do Brasil. Pain evaluation in cancer patients admitted to a teaching hospital of Northeastern Brazil

Pain in cancer patients under chemotherapeutic treatment
2013 Prospective, Describe cancer patients' pain evaluation and crossover study treatment in Clinical Oncology Ward.
Most common pain was nociceptive visceral pain, and neuropathic pain was the most difficult to control. There has been adequate pain control in patients admitted to the cancer ward.
2012 Quantitative, Evaluate cancer patients pain by means of descriptive, standardized scales validated to the Portucrossover study guese language
Moderate and sensory pain is present in most cancer patients leading to loss of energy to perform daily activities.

Category 3. Non-pharmacological methods to manage cancer pain

Massage in children with 2013 cancer: effectiveness of a protocol

Effect of therapeutic massage on mental health of cancer patients

Complementary techniques to control cancer symptoms

Non-pharmacological methods to control pediatric cancer pain: view of the nursing team

Pain in cancer patients under palliative care

Interventionist procedures for cancer pain management.
Prospective, Evaluate the efficacy of the implementation of longitudinal, a massage protocol to relieve pain of hospitarandomized, lized children with cancer. controlled study

2015 Systematic literature review

Evaluate the effect of therapeutic massage on mental health of cancer patients

2014 Literature re- Identify evidences in the scientific literature for view

2015 Descriptive, exloratory qua- trol pain used by nurses in hospitalized chilli-quantitative dren, check most widely used pain scales and study evaluate nursing team view about pain management with non-pharmacological methods.

2012 Quantitative, Describe the number and types of procedures descriptive, performed by the Pain Interventionist Medicine crossover study Center of a private hospital of São Paulo.
Massage seems to be a useful intervention to relieve pain in children with cancer, in spite of questions about the efficacy of this protocol.

Authors recommend its use due to its contribution to children's wellbeing and quality of life.

Therapeutic massage has short-term beneficial effects in terms of emotional wellbeing, physical and emotional discomfort, depressed mood, sleep pattern, relaxation and stress of cancer patients.

Scientific evidences show the benefit of non-pharmacological treatment to control signs and symptoms such as pain in oncology.

The need for training on pain measurement scales according to age, possible non-pharmacological methods used by nurses and their association with the nursing process has been identified.

Results have shown the presence of pain affecting quality of life and impairing daily life activities.

Results are in line with the literature and confirm the efficacy of interventionist procedures for different types of cancer pain. 


\section{CONCLUSION}

In terms of assistance, nurses have resources, management strategies and tools able to maximize assistance to painful cancer patients, such as pain evaluation scales, tailored appreciation of pain complaint, administration of continuous analgesics and rescue drugs, according to medical prescription, to contribute to dose titration adjustments and development and execution of nursing prescriptions to painful cancer patients.

Even if all resources and apparatus are needed, taking care of painful cancer patients goes beyond the administration of analgesic drugs, the performance of techniques and procedures and the execution of protocols; it is especially necessary to establish in professional/patient relationships empathy, interest and affective link aiming at relieving, comforting, supporting, promoting reestablishing and making patients happy so that their lives are not limited to cancer pain.

It is necessary to think on nurses' qualification for pain management, with regard to graduation teaching, bringing contemporaneity to qualification and better qualification of students to face the reality of the area and to bring excellence to doing in nursing.

\section{ACKNOWLEDGMENTS}

To Sônia Regina de Souza, doctor associate professor I of Universidade Federal do Estado do Rio de Janeiro who have cooperated in the interpretation of results, review and final formatting.

To Andrea dos Santos Garcia, specialist nurse in Medical-Surgical Nursing, who contributed to final formatting of the article.

\section{REFERENCES}

1. International Association for the Study of Pain (Associação Internacional para o Estudo da Dor)- IASP. Guia para o Tratamento da Dor em Contextos de Poucos Recursos. USA: IASP; 2010. 418p.

2. Ministério da Saúde (Brasil), Instituto Nacional de Câncer. Cuidados paliativos oncológicos: controle da dor. Rio de Janeiro: INCA; 2001.

3. Pollock RE. Manual de Oncologia Clínica da UICC. $8^{\mathrm{a}}$ ed. Săo Paulo: Fundação Oncocentro de São Paulo; 2006.

4. Infante AC. Dor iatrogênica em oncologia e sua prevençáo. Rev Dor. 2011;12(1):35-8.

5. Lima AD, Maia IO, Costa Júnior I, Lima JT, Lima LC. Avaliação da dor em pacientes oncológicos internados em um hospital escola do Nordeste do Brasil. Rev Dor. 2013;14(4):267-71.

6. Thomaz A. Dor oncológica: conceitualização e tratamento farmacológico. Rev Onco\&. 2010;24-9.

7. Mendes TR, Boaventura RP, Castro MC, Mendonça MA. Ocorrência de dor nos pacientes oncológicos em cuidados paliativos. Acta Paul Enferm. 2014;27(4):356-61.

8. Miceli AV. Dor crônica e subjetividade em oncologia. Rev Bras Cancerol. 2002;48(3):363-73.

9. Waterkemper R, Reibnitz KS, Monticelli M. [Dialogues with nurses about oncologic pain assessment of patients under palliative care]. Rev Bras Enferm. 2010;63(2):3349. Portuguese.

10. Chotolli $\mathrm{MR}$, Luize $\mathrm{PB}$. Métodos não farmacológicos no controle da dor oncológica pediátrica: visāo da equipe de enfermagem. Rev Dor. 2015;16(2):109-13.

11. Cunha FF, Rêgo LP. Enfermagem diante da dor oncológica. Rev Dor. 2015;16(2):142-5.

12. Waterkemper R, Reibnitz KS. Cuidados paliativos: a avaliação da dor na percepçáo de enfermeiras. Rev Gaúcha Enferm. 2010;31(1):84-91.

13. Silva JO, Araújo VM, Cardoso BG. Dimensão espiritual no controle da dor e sofrimento do paciente com câncer em estágio avançado. Relato de caso. Rev Dor 2015;16(1):71-4.

14. Macedo AC, Romanek FA, Avelar MC. Gerenciamento da dor no pós-operatório de pacientes com câncer pela enfermagem. Rev Dor. 2013;14(2):133-6.

15. Costa AI, Chaves MD. Dor em pacientes oncológicos sob tratamento quimioterápico. Rev Dor. 2012;13(1):45-9.

16. Minson FP, Assis FD, Vanetti TK, Sardá Júnior J, Mateus WP, Giglio AD. Procedimentos intervencionistas para o manejo da dor no câncer. Einstein. 2012;10(3):292-5.

17. Simôes AS. A dor irruptiva na doença oncológica avançada. Rev Dor. 2011;12(2):166-71.

18. Batalha LM, Mota AA. [Massage in children with cancer: effectiveness of a protocol]. J Pediatr. 2013;89(6):595-600. Portuguese.

19. Alves ML, Jardim MH, Gomes BP, Freitas OM. Efeito da massagem terapêutica na saúde mental das pessoas com patologia oncológica. Rev Port Enferm Saúde Mental. 2015; (nº spe2):119-22.

20. Costa AI, Reis PE. Técnicas complementares para controle de sintomas oncológicos. Rev Dor. 2014;15(1):61-4. 